\title{
EFFECT OF SHEAR WALL ON PERFORMANCE OF MULTISTOREY BUILDING
}

\author{
Mirza Aamir Baig ${ }^{*}{ }^{凶}$ (iD), Rizwan Rashid 2 四 \\ ${ }^{* 1,2}$ Department of Civil Engineering, Alfalah University, India
}

DOI: https://doi.org/10.29121/IJOEST.v4.i5.2020.111

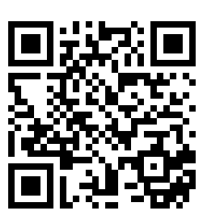

Article Type: Research Article

Article Citation: Mirza Aamir Baig, and Rizwan Rashid. (2020). EFFECT OF SHEAR WALL ON

PERFORMANCE OF MULTISTOREY

BUILDING. International Journal of Engineering Science Technologies, 4(5), 26-39.

https://doi.org/10.29121/IJOEST.v

4.i5.2020.111

Received Date: 1 September 2020

Accepted Date: 28 September 2020

Keywords:

Shear Wall

Damping

Response Spectrum

Seismic Coefficient Method

Ductility

\section{ABSTRACT}

Seismic force, predominantly being an inertia force depends on the mass of the structure. As the mass of the structure increases the seismic forces also increase causing the requirement of even heavier sections to counter that heavy forces. And these heavy sections further increase the mass of the structure leading to even heavier seismic forces. Structural designers are met with huge challenge to balance these contradictory physical phenomena to make the structure safe. The structure no more can afford to be rigid.

This introduces the concept of ductility. The structures are made ductile, allowing it yield in order to dissipate the seismic forces. A framed structure can be easily made ductile by properly detailing of the reinforcement. But again, as the building height goes beyond a certain limit, these framed structure sections (columns) gets larger and larger to the extent that they are no more practically feasible in a structure. There comes the role of shear walls. Shear walls provide ample amount of stiffness to the building frame resisting loads through in plane bending. But they inherently make the structure stiffer. So, there must be a balance between the amount of shear walls and frame elements present in a structure for safe and economic design of high-rise structures.

Here an attempt has been made to study the behavior of different structures of reinforced concrete with different heights with and without shear walls. Coupled shear walls have also been studied to understand the comparative merit or demerit of framed structures with shear wall structures. Studies have been carried out on sample model structures and analysis has been carried out by ETABS software. It has been ensured to consider sample models that represent the current practices in structural design to include different structural configurations. Models having varied structural configurations like framed, shear wall, coupled shear wall, central core shear wall, core in core etc. have been taken into consideration. The inherent asymmetry present in the structures have also been dealt.

The results have been tabulated and plotted to study their comparative behavior and interaction with each other. The findings of the study have been summarized and discussed. 


\section{INTRODUCTION}

More and more people are shifting to bigger cities for better lifestyle and easy livelihood. This causes concentration of population in cities. Constant effort is being made to find habitable land. As habitable land is constant and not increasing to meet the ever-growing demands of increasing population in cities. Horizontal growth is not possible. This leaves us with only option, rise vertically. This gives rise to tall high-rise structures. High rise building structures are both a necessity and a matter of sophistication and pride for structural engineers. Buildings crossing 25 to 30 storeys are a common phenomenon these days. But what happens to a structure as it crosses these height limits? Forces of nature in the form of earthquakes and cyclones starts playing brutal games with the structures. Higher the structure goes; higher it attracts the forces and wrath of nature in the form of seismic force.

Seismic force, predominantly being an inertia force depends on the mass of the structure. As the mass of the structure increases the seismic forces also increase causing the requirement of even heavier sections to counter that heavy forces. And these heavy sections further increase the mass of the structure leading to even heavier seismic forces. Structural designers are met with huge challenge to balance these contradictory physical phenomena to make the structure safe. The structure no more can afford to be rigid.

This introduces the concept of ductility. The structures are made ductile, allowing it yield in order to dissipate the seismic forces. A framed structure can be easily made ductile by properly detailing of the reinforcement. But again, as the building height goes beyond a certain limit, these framed structure sections (columns) gets larger and larger to the extent that they are no more practically feasible in a structure. There comes the role of shear walls. Shear walls provide ample amount of stiffness to the building frame resisting loads through in plane bending. But they inherently make the structure stiffer. So, there must be a balance between the amount of shear walls and frame elements present in a structure for safe and economic design of high-rise structures.

\subsection{OBJECTIVES}

Following are the main objectives of the work:

- Comparison of Effects of Seismic \& Wind Forces on High Rise Buildings with different structural configuration and to compare the key parameters.

- Comparison of behavior of different structures of reinforced concrete with different heights, with and without shear walls.

- Coupled shear walls have also been studied to understand the comparative merit or demerit of framed structures with shear wall structures.

\section{METHOD OF ANALYSIS}

\subsection{STATIC ANALYSIS}

The static method is the simplest one-it requires less computational effort and is based on the formulae given in the code. First, the design base shear is computed for the whole building and it is then distributed along the height of the building. The lateral forces at each floor level thus obtained are distributed to individual lateral load resisting elements.

\subsection{DYNAMIC ANALYSIS}

Dynamic analysis shall be performed to obtain the design seismic forces and its distribution to different levels along the height of building and to the various lateral load resisting elements in following cases:

- Regular Building - Greater than $40 \mathrm{~m}$ height in zone IV and V and those greater than $90 \mathrm{~m}$ in height in zone II and III.

- Irregular building - All framed buildings higher than $12 \mathrm{~m}$ in zone IV and V, and those greater than 40 $\mathrm{m}$ height in zone II and III.

- For irregular building lesser than $40 \mathrm{~m}$ in height in zone II and III, dynamic analysis even though not mandatory, is recommended. 


\subsubsection{RESPONSE SPECTRUM METHOD}

Response spectrum method is simply a plot of peak or steady state response (displacement, velocity or acceleration of a series of oscillators of varying natural frequency that are forced into motion by same base vibration or shock.

\subsubsection{NON- LINEAR TIME HISTORY ANALYSIS}

It is an analysis of dynamic response of structure at each increment of time, when its base is subjected to any specific ground motion time history (compatible time history for medium soil IS-1893:2002-Part 1)

\section{MODELS CONSIDERED FOR ANALYSIS}

Following six types of models have been considered for analysis. It was attempted to choose models that are representative of actual building types that are being constructed nowadays. Type A is regular framed structure with columns. Type B hybrid framed structure with shear wall in periphery and columns. Type $C$ hybrid framed structure with shear wall in center and columns. Type D is tube structure. Type E is hybrid framed structure with lift core in center. Type $\mathrm{F}$ is tube in tube system.

Table 1: Structural Description

\begin{tabular}{|c|c|}
\hline Model ID & Description \\
\hline Type A & Regular Frame Structure with column. \\
\hline Type B & hybrid framed structure with shear wall in periphery and columns \\
\hline Type C & hybrid framed structure with shear wall in center and columns \\
\hline Type D & Tube structure with shear walls and columns \\
\hline Type E & hybrid framed structure with lift core in center \\
\hline Type F & tube in tube system \\
\hline
\end{tabular}

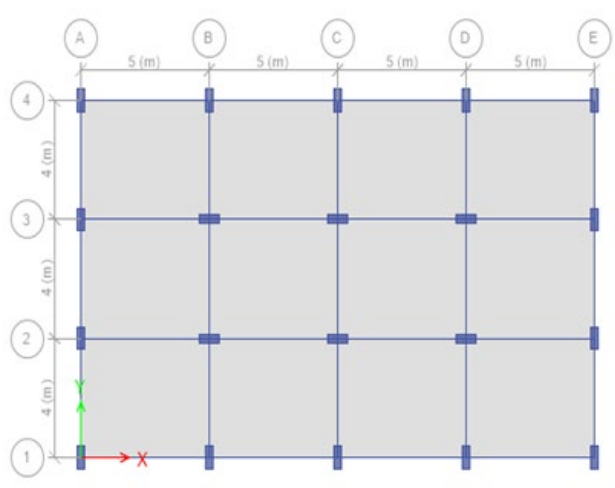

Type A: regular framed structure

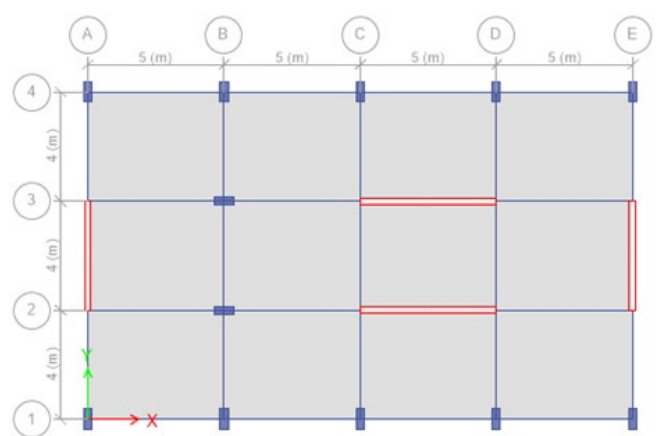

Type C: hybrid framed structure with shear wall in center and columns

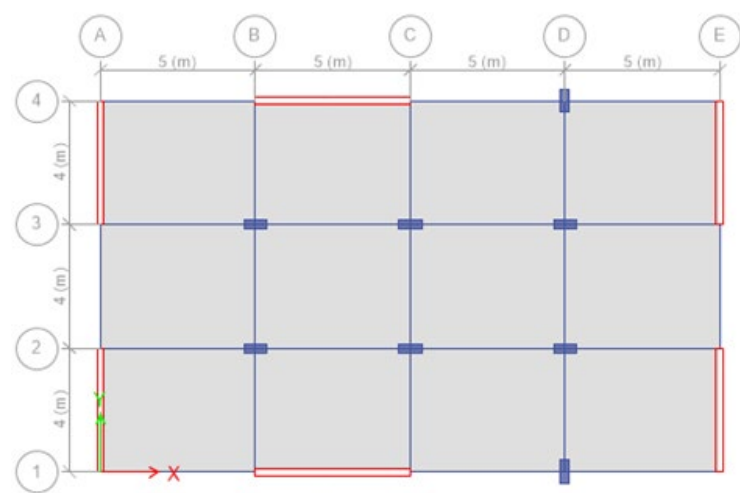

Type B: hybrid framed structure with shear wall

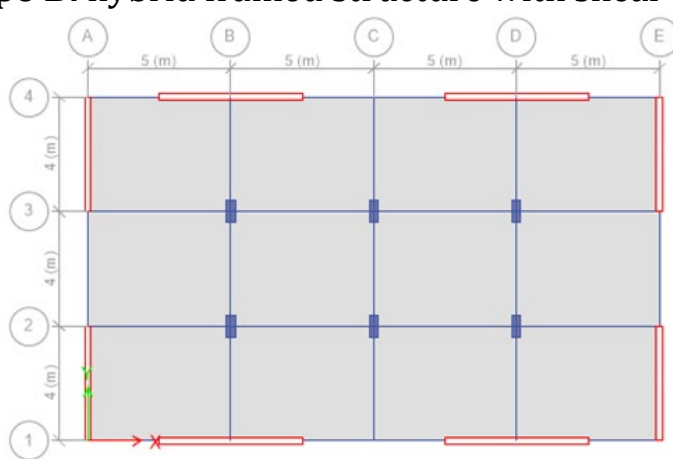

Type D: tube structure 


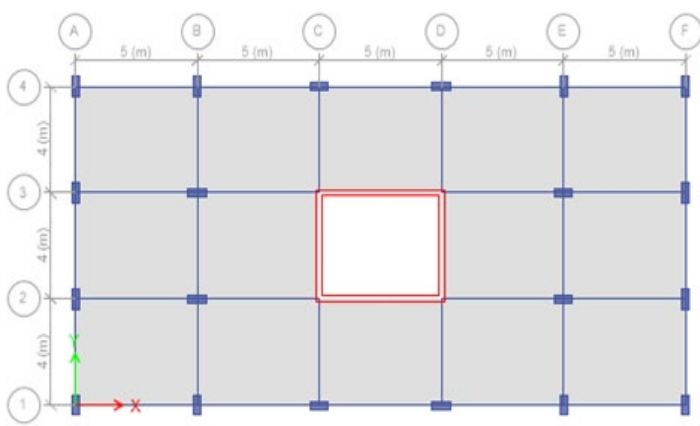

Type E: is hybrid framed structure with lift core in center

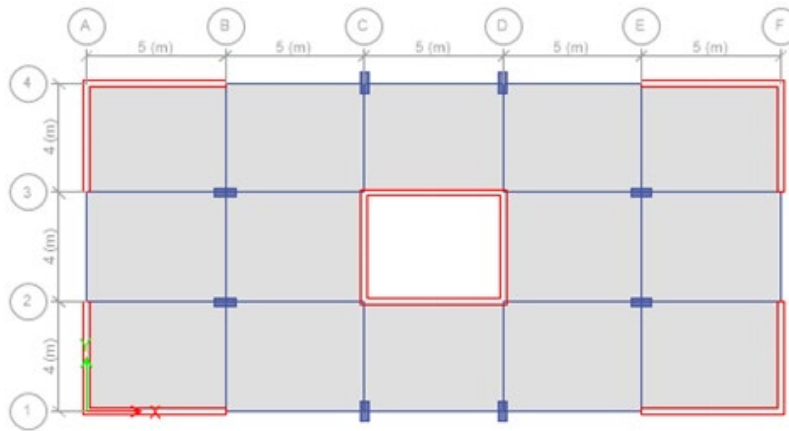

Type F: tube in tube system

Figure 1: Models Considered for Analysis

\section{MODEL PARAMETERS}

For the analysis of multi storied building six types of models have been considered for analysis. Type A is regular framed structure with columns. Type B hybrid framed structure with shear wall in periphery and columns. Type C hybrid framed structure with shear wall in centre and columns. Type D is tube structure. Type E is hybrid framed structure with lift core in centre. Type $\mathrm{F}$ is tube in tube system. All the different types of models considered are analysed for different height also.

In the current study main goal is to compare the Static and Dynamic Analysis of different types of building. All the different types of models considered are analysed for 10,25 \& 50 storey.

In the current study main goal is to compare the Static and Dynamic Analysis of different types of building.

Design Parameters- Here the Analysis is being done for $\mathrm{G}+50$, (rigid joint regular frame) building by computer software using ETABS.

Design Characteristics: - The following design characteristics are considered for Multi-storey rigid jointed frames

\section{Seismic Load}

As per IS: 1893, Noida is located in Seismic Zone IV.

Design base shear, V = Z I W Sa/2 R g

Wind Load

The wind velocity at Noida is $47 \mathrm{~m} / \mathrm{s}$. The other parameter of wind load as per IS: 875 (Part-3).

Table 2: Model Parameters

\begin{tabular}{|c|c|c|}
\hline S.No & Particulars & Dimension/Size/Value \\
\hline 1. & Model & $\mathrm{G}+10,25,35 \& 50$ \\
\hline 2. & Seismic Zones & IV \\
\hline 3. & Floor height & $3 \mathrm{M}$ \\
\hline 4. & Basement & $4 \mathrm{M}$ \\
\hline 6. & Plan size & $25 \mathrm{~m} \times 20 \mathrm{~m}$ \\
\hline 8. & Size of columns & $0.3 \mathrm{mx} 0.75 \mathrm{~m}$ \\
\hline 9. & Size of beams & 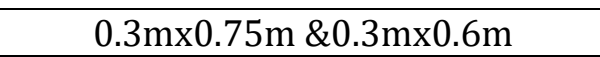 \\
\hline 10 & Shear Walls & $0.23 \mathrm{~m}$ \\
\hline 11. & Thickness of slab & $125 \mathrm{~mm}$ \\
\hline 12. & Earthquake load & As per IS-1893-2002 \\
\hline 13. & Type of soil & Type -II, Medium soil as per IS-1893 \\
\hline
\end{tabular}

\section{ANALYSIS RESULTS AND DISCUSSIONS}

Models of Type A shows regular behavior where ductility may be provided by proper detailing as per IS 13920: 1993. They exhibit predictable behavior during dynamic shaking assuming not much asymmetry. But the main problem is that they are not capable of providing sufficient lateral stiffness to the structures. The column sizes keep 
on growing larger and larger as we go above 10 storey range and practically becomes impossible to design an economical structure after 25 storeys. Compared to all other models, Type A exhibits the highest time periods and thus lesser base shear values. This does seem advantageous, but only till 25 storey range.

Models of Type B and D with shear walls are kind of Tube structures where the shear walls are placed in the periphery of the buildings. The internal columns help in transferring the maximum gravity load of the building to the foundation, while the periphery shear walls are taking the majority of lateral loads. They exhibit lesser time periods but higher amount of base shear also. The good thing about these structures is that they are sufficiently rigid to take care of the additional base shear encountered by these structures. As seen by the tabulated results and plots, they also exhibit lower values of storey displacements and drifts. The case study model showed similar vibration behavior as compared to these models. These strcutures can comfortably go beyond 35 storeys with economy and safely till 50 storeys.

Type $\mathrm{C}$ and Type $\mathrm{E}$ were shear core buildings. These types of structures are very common with buildings having lift core at the center of the building. The idea behind these structures is similar to tube structures with the only difference being that these structures are not that robust in resisting base shear as shown by Tube structures. These structures are ideal for 10 to 15 storey structures and low-rise structures also. They are not practical after 25 storeys.

Type $\mathrm{F}$ was a core in core or tube in tube structures. These are highly robust and stiff structures with sufficient ductility. These structures can be constructed very high. Structures up to 50 storeys can be comfortably erected applying these configurations. These structures show high stiffness, lower time periods compared to other types and lower displacements also.

\subsection{COMPARISON OF 10 STOREY BUILDINGS}

Table 3: Base Shear $(\mathrm{kN})$

\begin{tabular}{|c|c|c|c|c|c|c|}
\hline \multicolumn{7}{|c|}{ Base Shear (KN) } \\
\hline Load & Type A & Type B & Type C & Type D & Type E & Type F \\
\hline EQX & 1290.55 & 1560.97 & 717.63 & 1542.54 & 1914.97 & 1000.23 \\
\hline EQY & 1290.55 & 1560.97 & 717.63 & 1542.54 & 1914.97 & 1000.23 \\
\hline SPEC X & 629.9654 & 954.4855 & 595.0223 & 574.9217 & 1311.5169 & 1184.827 \\
\hline SPEC Y & 669.8013 & 935.0808 & 548.095 & 876.7248 & 1172.8936 & 975.8446 \\
\hline
\end{tabular}

Type B and Type E are attracting the maximum base shear, which is in line with their time period values.

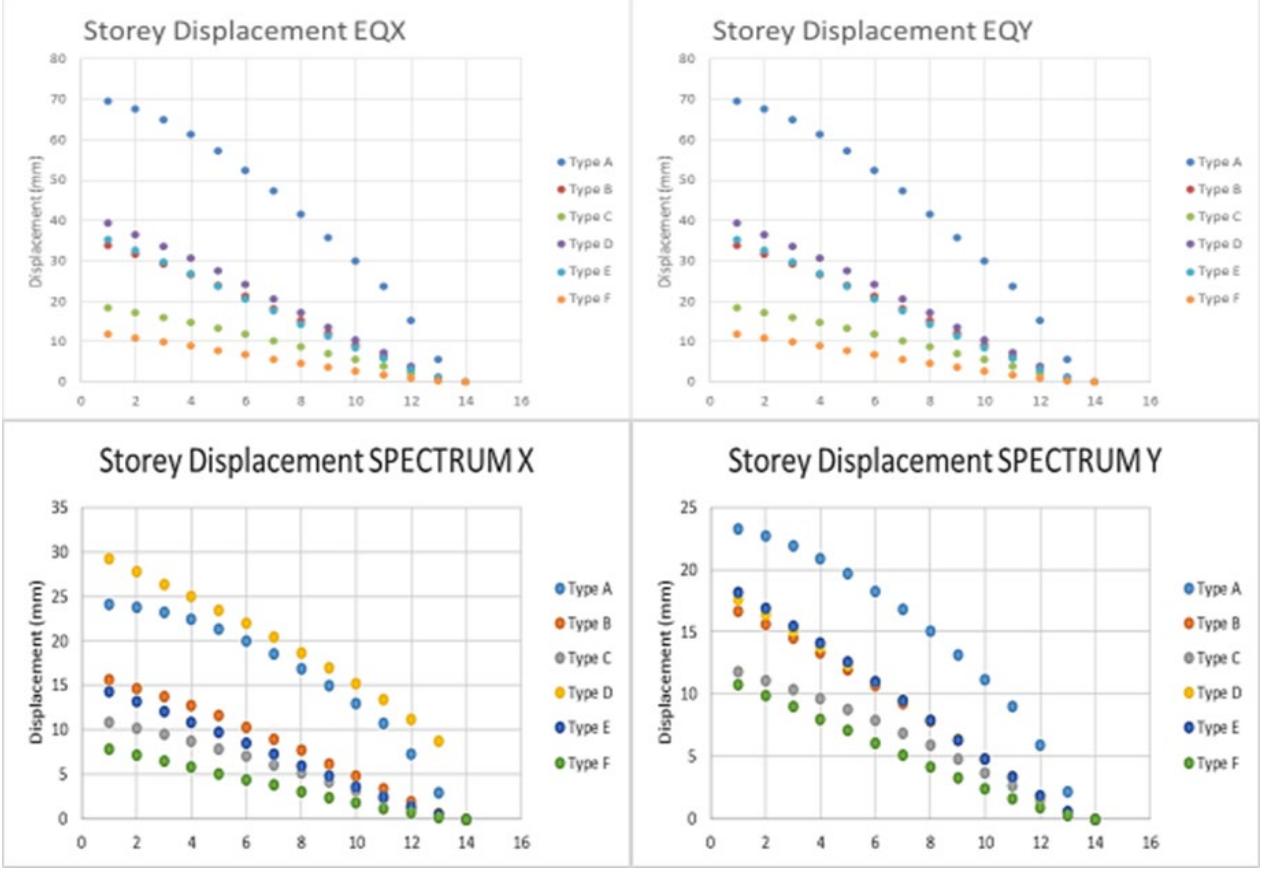

Figure 2: Storey displacement in static and dynamic seismic load. 
Effect of Shear Wall on Performance of Multistorey Building

Table 4: comparison for wind and seismic load

\begin{tabular}{|c|c|c|c|c|c|c|c|c|c|}
\hline \multicolumn{5}{|c|}{ TYPE A 10 STOREY } & \multicolumn{5}{|c|}{ TYPE B 10 STOREY } \\
\hline \multirow{2}{*}{ Story } & Elevation & yzx & FoX & $\mathrm{SPFCX}$ & Story & Elevation & WLXX & EQX & SPECX \\
\hline & $\frac{\text { Elevanod }}{\mathrm{m}}$ & $\frac{\mathrm{WLN}}{\mathrm{mm}}$ & $\frac{\mathrm{zQX}}{\min }$ & $\frac{\mathrm{SPECX}}{\mathrm{mm}}$ & & $\mathrm{m}$ & $\mathrm{mm}$ & $\operatorname{mm}$ & $\mathrm{mm}$ \\
\hline 10THFLOOR & 41.6 & 24.8 & 75.5 & 24.1 & 10TH FLOOR & 41.6 & 9.9 & 31.4 & 15.6 \\
\hline 9TH FLOOR & 38.6 & 24.4 & 74.2 & 23.8 & 9THFLOOR & 38.6 & 9.4 & 29.5 & 14.7 \\
\hline 8TH FLOOR & 35.6 & 23.9 & 71.9 & 23.2 & 8TH FLOOR & 35.6 & 8.8 & 27.5 & 13.8 \\
\hline TTH FLOOR & 32.6 & 23.1 & 68.6 & 22.4 & TTH FLOOR & 32.6 & 8.2 & 25.3 & 12.7 \\
\hline 6THFLOOR & 29.6 & 22 & 64.5 & 21.3 & 6TH FLOOR & 29.6 & 7.5 & 22.9 & 11.6 \\
\hline 5TH FLOOR & 26.6 & 20.8 & 59.7 & 20 & 5TH FLOOR & 26.6 & 6.7 & 20.3 & 10.3 \\
\hline 4TH FLOOR & 23.6 & 19.3 & 54.4 & 18,5 & 4TH FLOOR & 23.6 & 5.9 & 17.5 & 9 \\
\hline 3RD FLOOR & 20.6 & 17.7 & 48.6 & 16.9 & 3RD FLOOR & 20.6 & 5.1 & 14.7 & 7.7 \\
\hline 2ND FLOOR & 17.6 & 15.8 & 42.5 & 15 & 2ND FLOOR & 17.6 & 4.1 & 11.8 & 6.2 \\
\hline 1ST FLOOR & 14.6 & 13.7 & 36.1 & 13 & IST FLOOR & 14.6 & 3.2 & 9 & 4.8 \\
\hline GROUD FLOOR & 11.6 & 11.4 & 29.2 & 10.7 & GROUD FLOOR & 11.6 & 2.3 & 6.3 & 3.4 \\
\hline 1ST BASEMENT & 8 & 7.8 & 19.5 & 7,3 & 1ST BASEMENT & 8 & 1.3 & 3.5 & 19 \\
\hline 2ND BASEMENT & 4 & 3.2 & 7.7 & 2.9 & 2ND BASEMENT & 4 & 0.4 & 1.1 & 0.6 \\
\hline Base & 0 & 0 & 0 & 0 & Base & 0 & 0 & 0 & 0 \\
\hline \multirow{2}{*}{\multicolumn{5}{|c|}{ TYPE C 10 STOREY }} & & & & & \\
\hline \multirow{2}{*}{ Story } & Elevation & WLX & & & \multicolumn{5}{|c|}{ TYPE D 10 STOREY } \\
\hline & $m$ & $\mathrm{~mm}$ & $\mathrm{~mm}$ & $\operatorname{mm}$ & Story & Elevation & WLX & EQX & SPEX \\
\hline 10TH FLOOR & 41.6 & 10.3 & 15.4 & 10.9 & $10 T H$ EI OOR & $\mathrm{m}$ & $\mathrm{mm}$ & $\mathrm{mm}$ & $\operatorname{mm}$ \\
\hline 9TH FLOOR & 38.6 & 9.7 & 14.4 & 10.2 & $\begin{array}{l}\text { 10TH FLOOR } \\
\text { 9THELOOR }\end{array}$ & 41.6 & 11.2 & 35.0 & 10.7 \\
\hline 8TH FLOOR & 35.6 & 9.1 & 13.4 & 9.5 & $\frac{91 H F L O O R}{8 T H E L O O R}$ & 38.6 & 10.3 & 32.7 & 15.4 \\
\hline TTHFLOOR & 32.6 & 8.4 & 12.2 & 8.8 & $\frac{\text { 8THFLOOR }}{\text { TTHFLOOR }}$ & 35.6 & 9.4 & 29.8 & $\frac{14}{126}$ \\
\hline 6THFLOOR & 29.6 & 7.7 & 11 & 7,9 & $\frac{71 H F L O O R}{6 T H F L O O R}$ & 32.6 & $\frac{8.5}{7.6}$ & 20.7 & $\frac{12.0}{112}$ \\
\hline 5THFLOOR & 26.6 & 6.9 & 9.7 & 7,1 & 5TH FLOOR & $\frac{29.6}{26.6}$ & $\frac{1.0}{6.7}$ & 20.4 & $\frac{11.2}{9.7}$ \\
\hline 4TH FLOOR & 23.6 & 6.1 & 8.4 & 6.1 & 4TH FLOOR & 23.6 & 5.7 & 17.2 & 8.2 \\
\hline 3RD FLOOR & 20.6 & 5.2 & 7 & 5.2 & 3RD FLOOR & 20.6 & 4.7 & 14 & 6.8 \\
\hline 2ND FLOOR & 17.6 & 4.2 & 5.6 & 4.2 & 2ND FLOOR & 17.6 & 3.7 & 11 & 5.3 \\
\hline IST FLOOR & 14.6 & 3.3 & 4.3 & 3.2 & IST FLOOR & 14.6 & 2.8 & 8.1 & 4 \\
\hline GROUD FLOOR & 11.6 & 2.3 & 3 & 2.3 & GROUD FLOOR & 11.6 & 1.9 & 5.5 & 2.7 \\
\hline 1ST BASEMENT & 8 & 1.3 & 1.6 & 1.2 & 1ST BASEMENT & 8 & 1 & 2.9 & 1.4 \\
\hline 2ND BASEMENT & 4 & 0.4 & 0.5 & 0,4 & 2ND BASEMENT & 4 & 0.3 & 0.8 & 0.4 \\
\hline Base & 0 & 0 & 0 & 0 & Base & 0 & 0 & 0 & 0 \\
\hline
\end{tabular}


International Journal of Engineering Science Technologies 




Figure 3: displacement for wind \& seismic load.

Wind is not the governing case, as clearly seen by the displacements shown by the structures.

\subsection{COMPARISON OF 25 STOREY BUILDINGS}

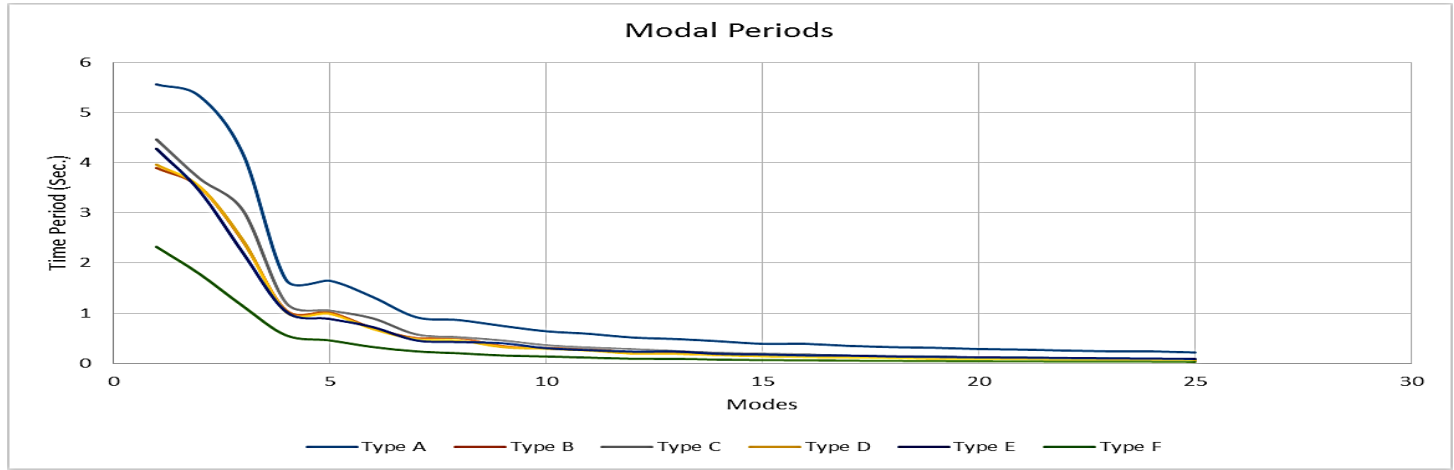

Figure 4: Modal period.
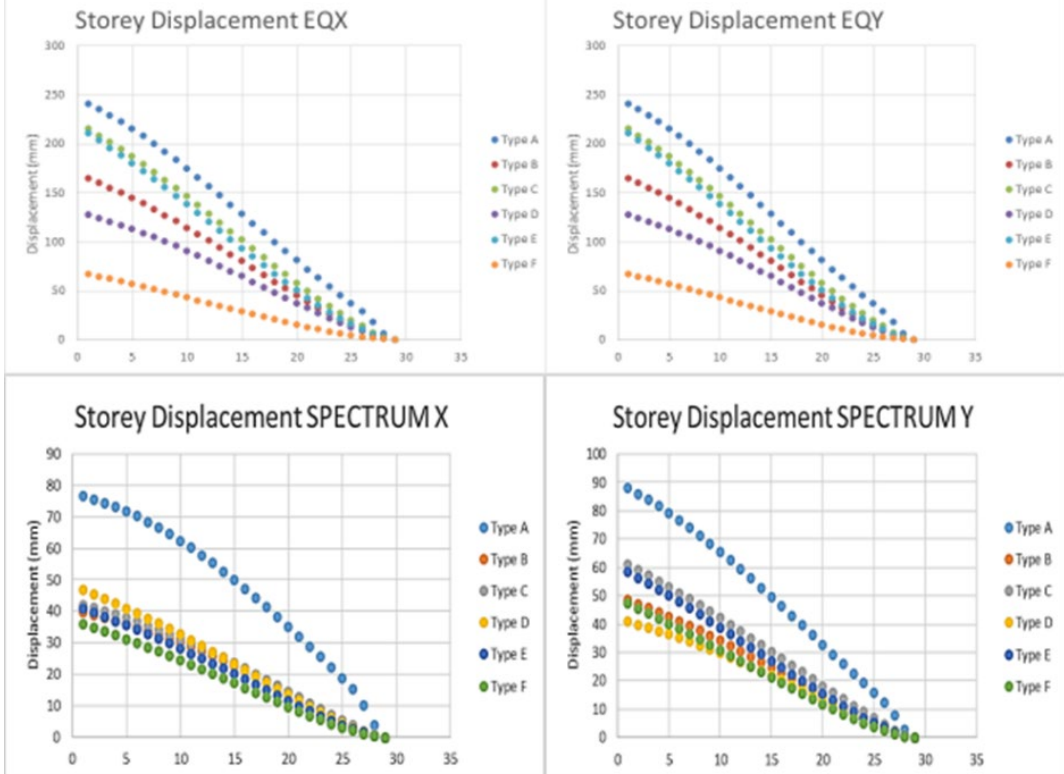

Figure 5: storey displacement in static and dynamic seismic load. 
Effect of Shear Wall on Performance of Multistorey Building

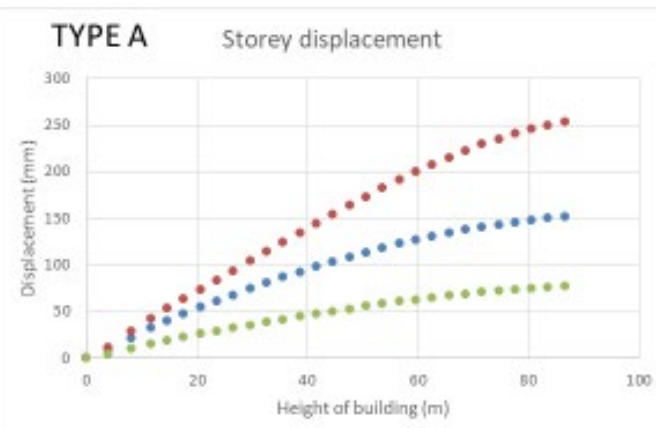

TYPE B Storey displacement

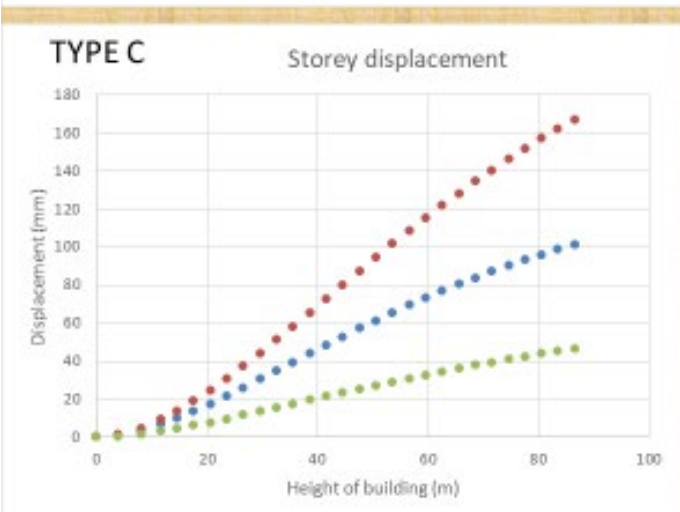

- wrxmm •Eax mm - soecx mm
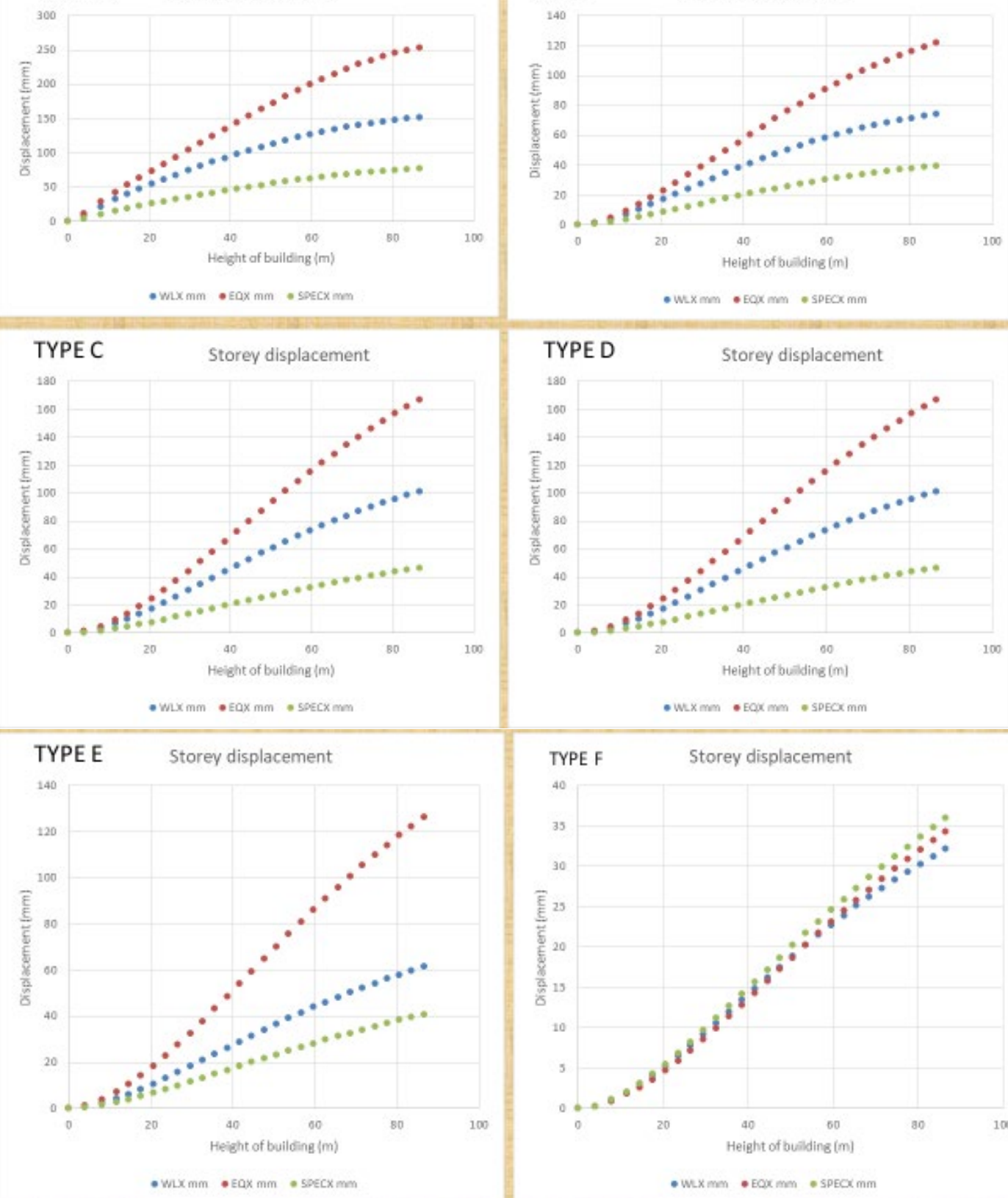

- Wuxmm - Eox mm e specrman

TYPE D Storey displacement

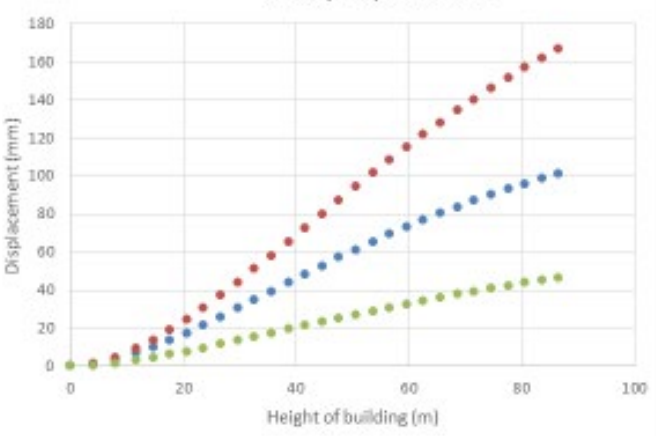

- wLX men - EQX mmon - SPECO mm

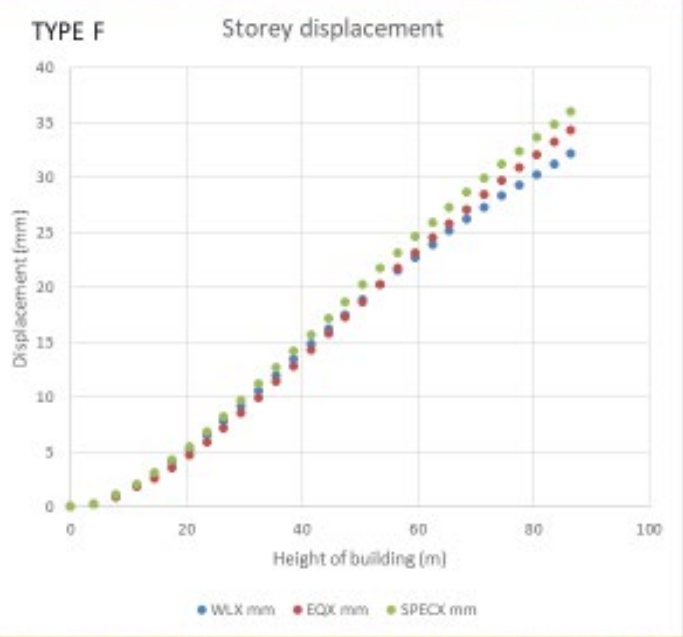

Figure 6: Displacement for wind \& seismic load.

\subsection{COMPARISON OF 35 STOREY BUILDINGS}



Figure 7: Modal period. 

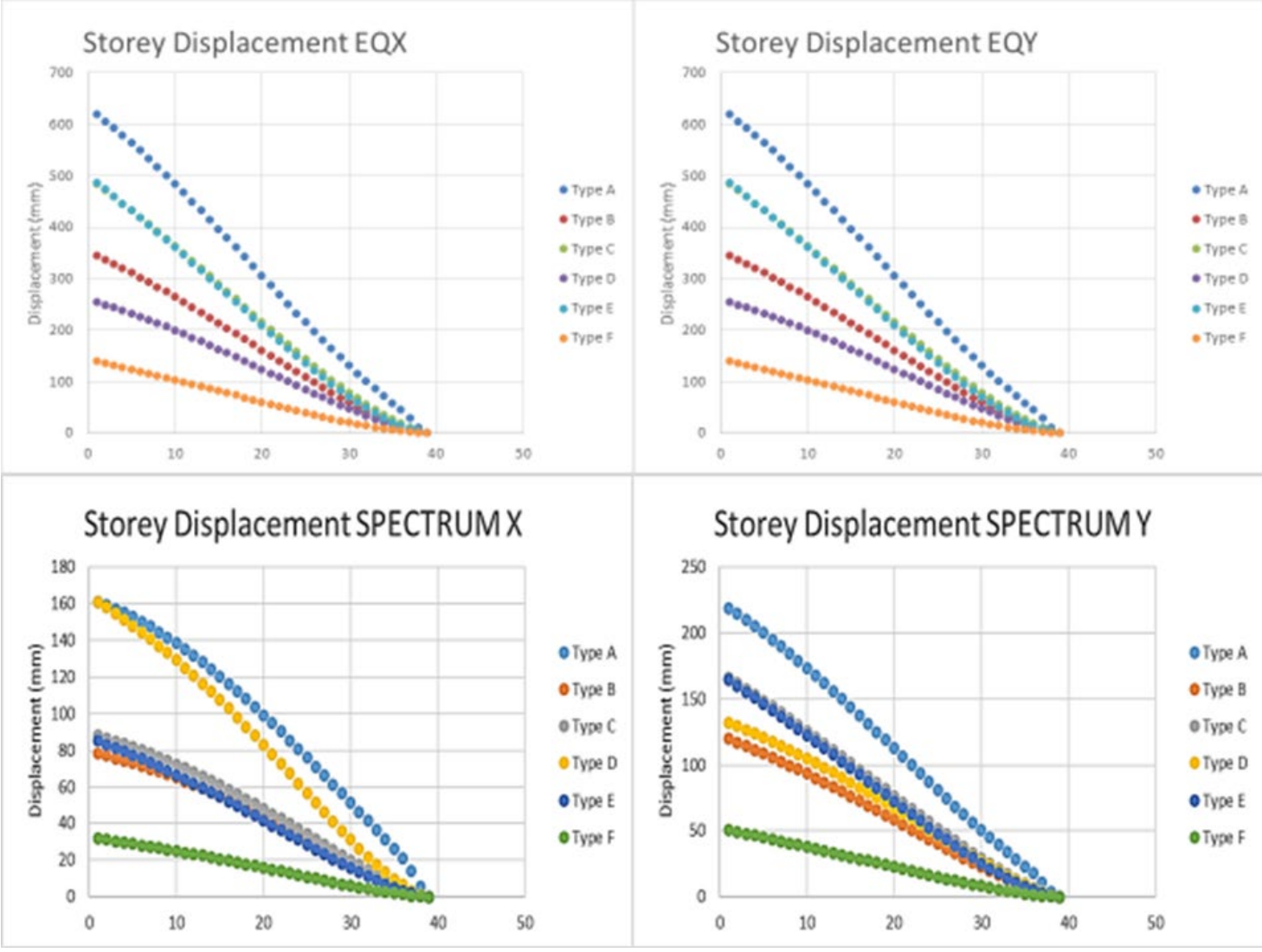

Figure 8: storey displacement in static and dynamic seismic load.
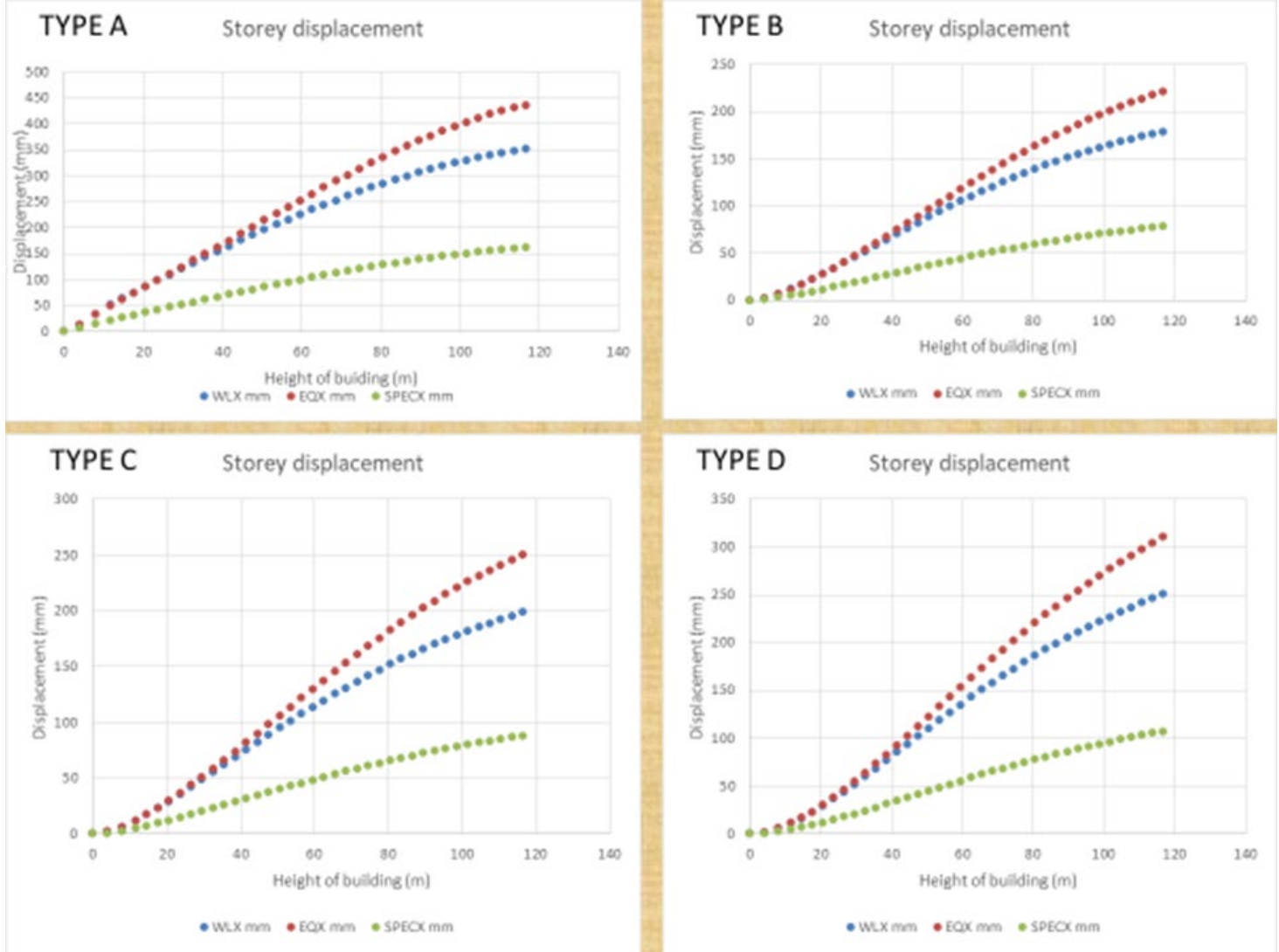


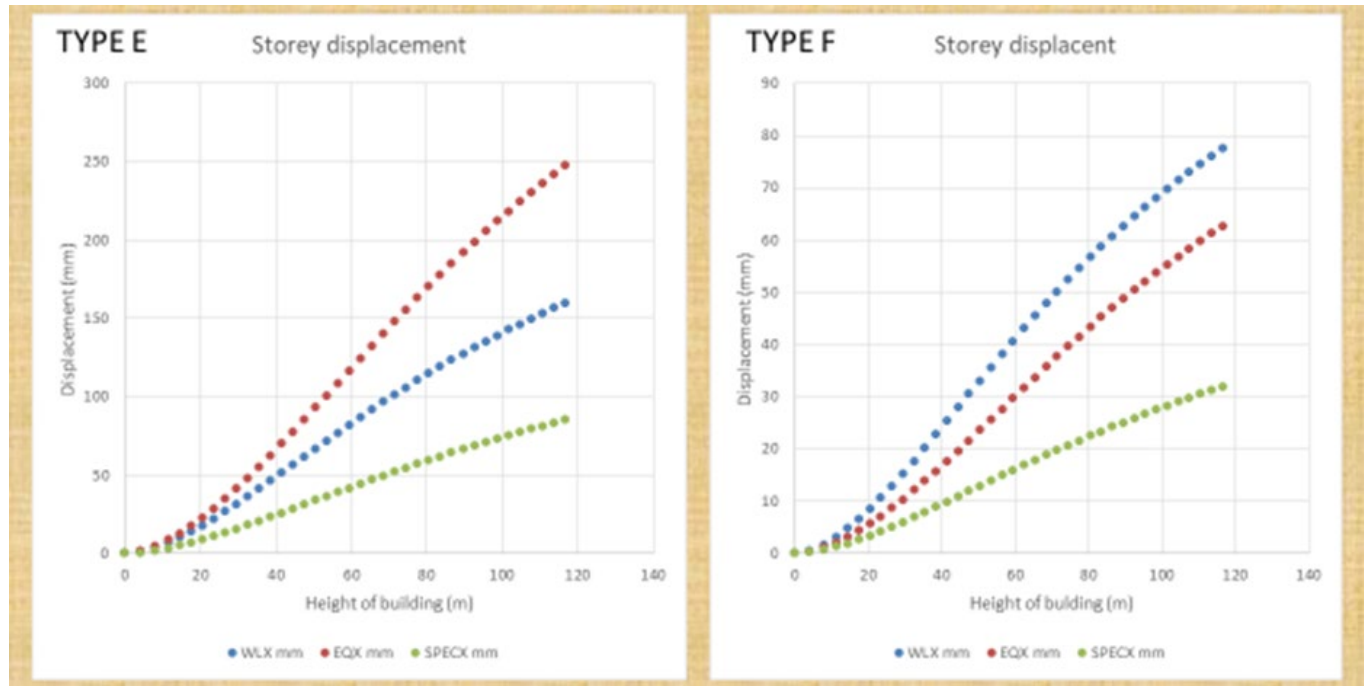

Figure 9: displacement for wind \& seismic load.

\subsection{COMPARISON OF 50 STOREY BUILDINGS}

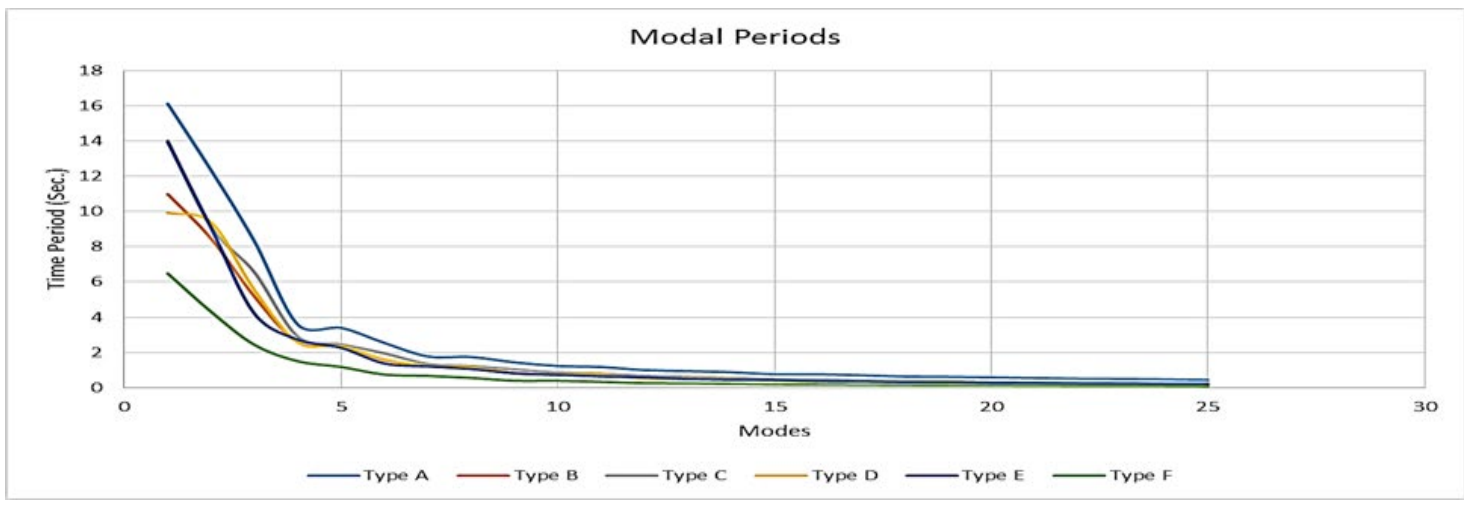

Figure 10: Modal period.


Figure 11: storey displacement in static and dynamic seismic load. 

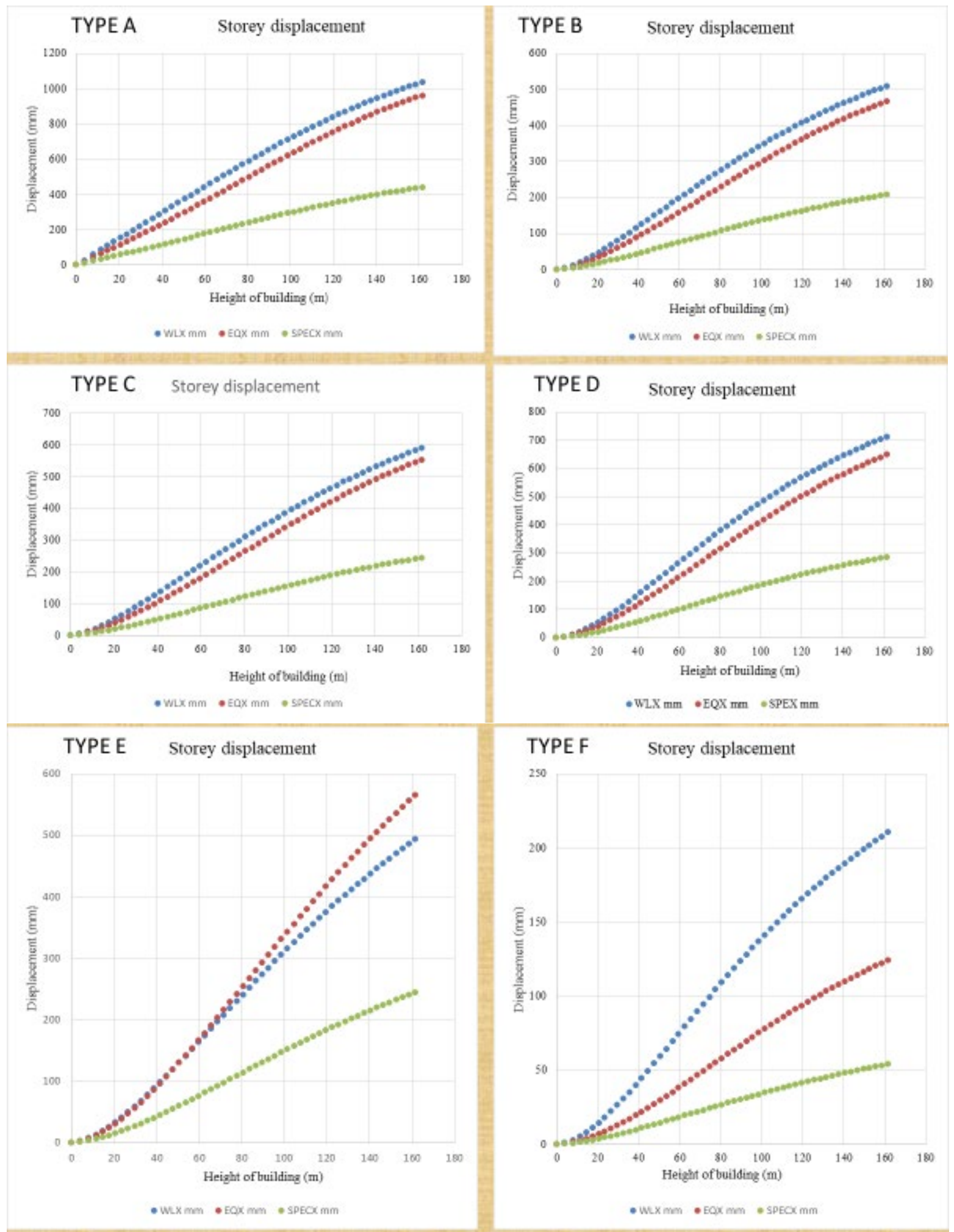

Figure 12: displacement for wind \& seismic load

The results show that our case study model is to be made more ductile than all the other models considered. It may also be concluded that the models taken for study could be less stiff and the sections could be lighter to make the structures more economical. 
Effect of Shear Wall on Performance of Multistorey Building
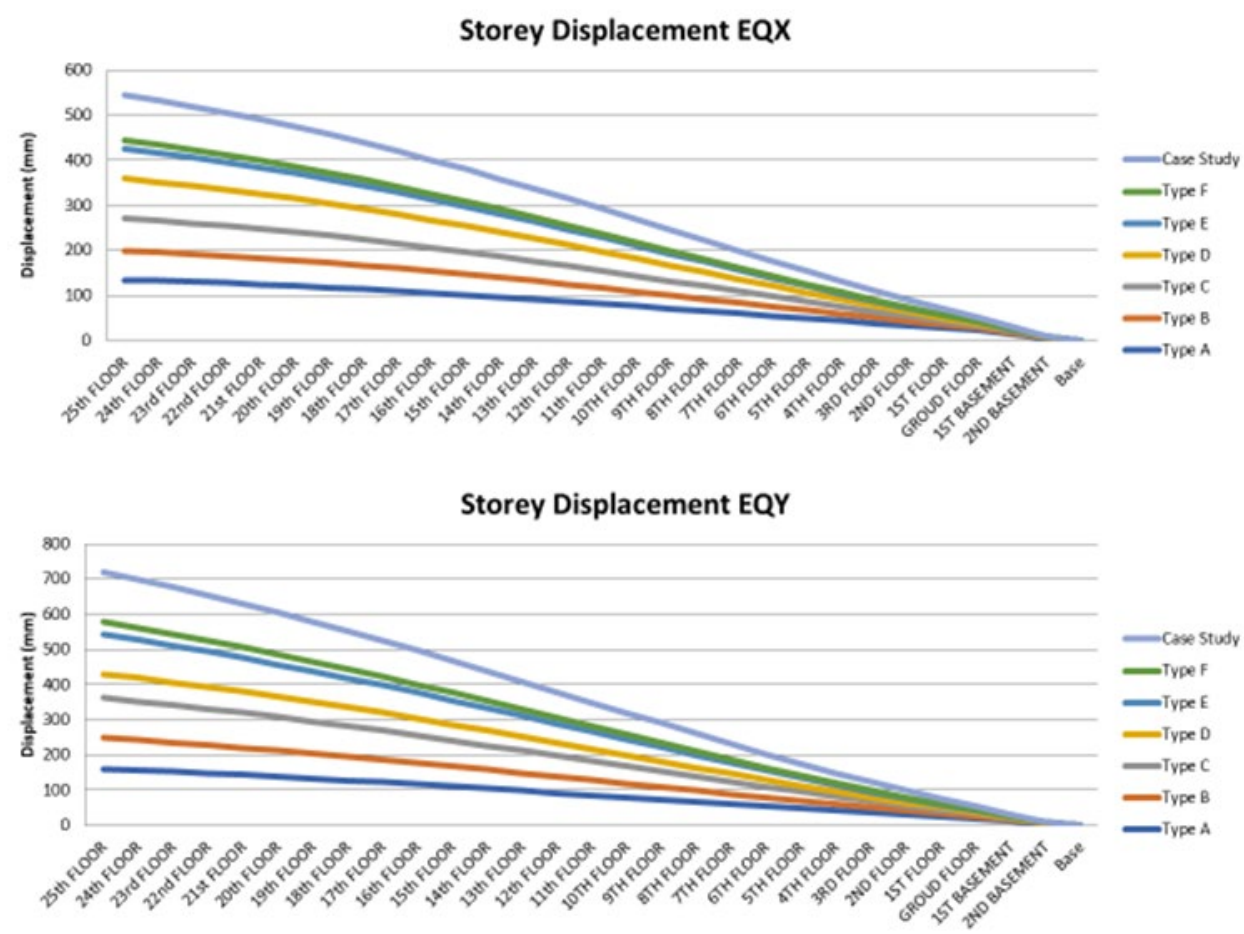

Figure 13: Storey displacement for static seismic load
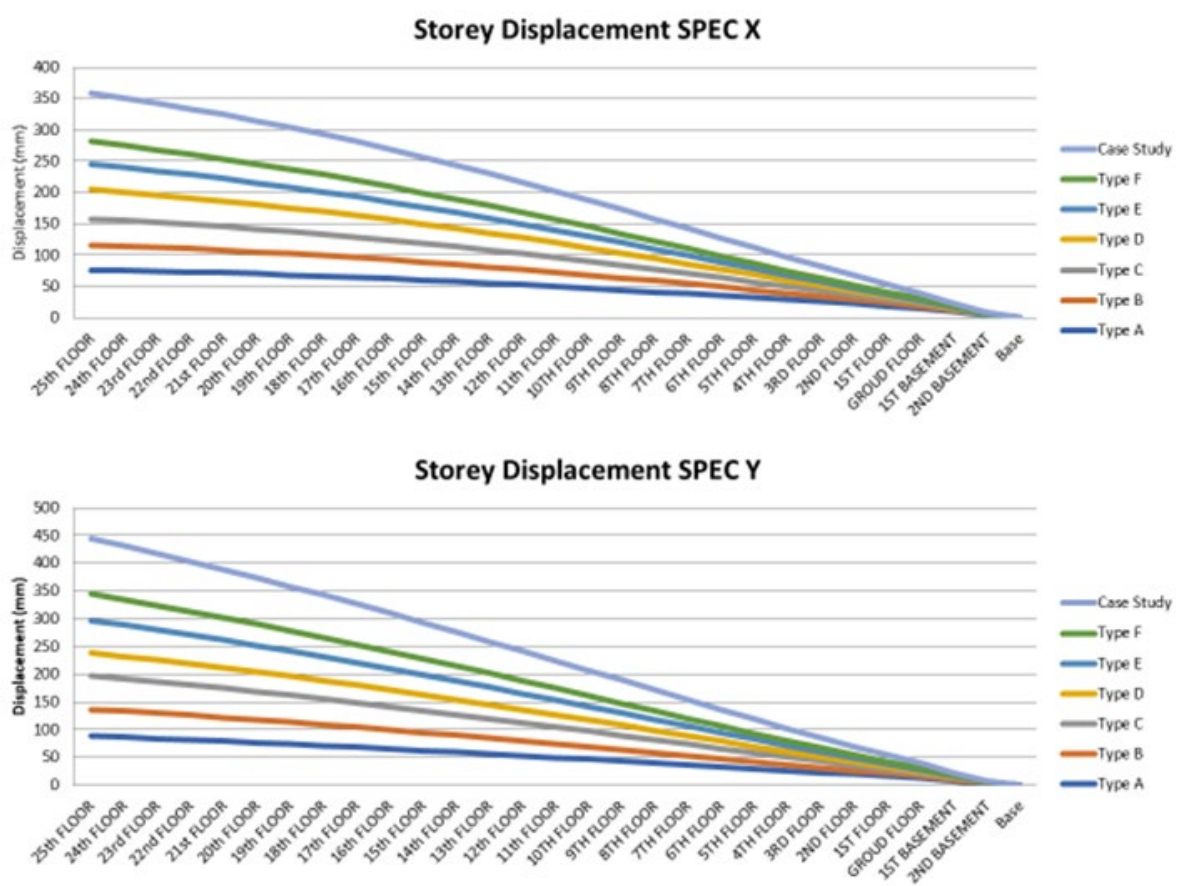

Figure 13: Storey displacement for dynamic seismic load

\section{CONCLUSIONS}

The approach for design of structures for wind and earthquake are diagonally apart. Wind forces are generally push forces that tries to topple or bend the structure vertically. They are applicable on the exposed face of the structures. In order to safeguard the structure for wind, one very simple solution can be to make the structure heavier. Heavier the structure, better its ability to resist wind forces. 
But earthquake forces are totally different. They are basically inertia forces, which depend on the mass of the structures. The structures on action of earthquake forces rarely topple over or fall down. They actually collapse just under its own vertical axis. Since earthquake forces depend upon the weight/mass of the structure, heavier the structure, more earthquake force it attracts. The idea is to make the structure lighter. Lighter the structure, better it is for the structure to resist earthquake forces.

Structures within 10 storey are generally governed by earthquake loads and wind does not play a vital role. Generally, in this range type A framed are preferred over shear wall structures. Provision of shear walls with lift core as given in Type $\mathrm{C}$ are also common. But here the shear walls alone do not impact the lateral stability of the structures considerably. Tube structures and tube in tube structures are not required in this height zone. They are often less economical than simple framed structures.in general hybrid structures with combinations of shear walls and columns are provided. The economy of the structures often depends upon the relative presence of shear walls and columns in appropriate ratios. Overall, it can be concluded that framed structures are economical for structures below 10 storeys.

Structures in the range of 25 storey are supposed to be sufficiently ductile to dissipate higher level of base shear but just enough stiffness not to attract seismic forces. Type A framed structures can be constructed but it is often seen that the section requirement at the bottom storey are very high this causes accessibility issues as often parking is planned at these levels. Coupled shear wall structures $\&$ hybrid structures with shear walls at center and periphery are best suited for this storey range. Tube structures and tube in tube structures are not required here here also the economy of the structures often depends upon the relative presence of shear walls and columns in appropriate ratios. Overall, it can be concluded that hybrid structures with shear walls at center and periphery are best suited.

Structures in the range of 35 storey are expected to vibrate in higher modes of vibrations and the effect of higher modes of vibration often causes the lateral load resisting elements requiring huge sections at middle half of the building. consequently, the columns size requirements at the bottom storeys does not remain feasible at all. However, hybrid structures with shear walls at center and periphery can be constructed but the requirement of shear walls is enhanced which further causes increase in base shear. so, the sections required for shear walls also are very high at the bottom storey. additionally, presence of too many shear walls to tackle huge base shear causes the structures to be very rigid which in itself is not a desirable feature. Tube and tube in tube structures are suitable for this storey range.

Structures in the range of 50 and above stories are expected to vibrate in even higher modes of vibration. This causes the use of simple framed, or simple shear wall structures practically impossible to design. We have to go for innovative structural configurations like braced shear walled framed structures, tension structures, pretension structures etc. No particular structural configuration can be assumed to behave satisfactorily in this storey range. Tube and Tube in Tube structures with spandrel beams may prove to be useful, but the decision of the structural configuration depends on the structure at hand.

\section{SOURCES OF FUNDING}

This research received no specific grant from any funding agency in the public, commercial, or not-for-profit sectors.

\section{CONFLICT OF INTEREST}

The author have declared that no competing interests exist.

\section{ACKNOWLEDGMENT}

None.

\section{REFERENCES}

[1] Datta. T. K Seismic analysis of structures, John Wiley \& Sons (Asia) Pte ltd, 2010

[2] Chopra A K, Dynamics of Structures

International Journal of Engineering Science Technologies 
[3] Jain. S K, IIT Roorkee Review of Indian seismic code, IS 1893 (Part 1): 2002

[4] Reddy K. R. C. Sandip A. Tupat (2012). "The effect of zone factors on wind and earthquake loads of high-rise structures"

[5] Jain. S K and Navin C Nigam "Historical developments and current status of Earthquake Engineering in India

[6] Mohapatra, A.K. \& Mohanty, W.K. "An Overview of Seismic Zonation Studies in India"

[7] Dean Kumar B. \& Swami B.L.P. "Wind effects on tall building frames-influence of dynamic parameters"

[8] Varalakshmi V., Shiva Kumar G., Sunil Sarma R. (2014) "Analysis and Design of G+5 Residential Building"

[9] Bagheri Bahador, Firoozabad Salimi Ehsan, and Yahyaei Mohammadreza (2012) "Comparative Study of the Static and Dynamic Analysis of Multi-Storey Irregular Building"

[10] Sharma Mohit \& Maru Savita (2011) "Dynamic Analysis of Multistoried Regular Building"

[11] Shahzad Jamil Sardar and Umesh. N. Karadi (2014) "effect of change in shear wall

[12] Location on storey drift of multistorey building subjected to lateral loads"

[13] Yousuf Mohammed \& shimpale P.M. (2013) "Dynamic Analysis of Reinforced Concrete Building with Plan Irregularities"

[14] Anshuman. S, Dipendu Bhunia, Bhavin Ramjiyani (2011) "Solution of Shear Wall Location in Multi-Storey Building" 